\title{
Middle Givetian to late Famennian (Middle to Late Devonian) conodonts from the northern margin of Gondwana (Kerman region, Central Iran)
}

\author{
Zamani Fatane $^{1}$, Yazdi Mehdi ${ }^{2 *}$, Bahrami Ali ${ }^{3}$, Girard Catherine ${ }^{4}$, Spalletta Claudia ${ }^{5}$ Ameri Hamed ${ }^{6}$. \\ ${ }^{1}$ Department of Geology, Faculty of Science, University of Isfahan, Isfahan 81746, Iran. zamani.paleo@gmail.com \\ $2^{2 *}$ Department of Geology, Faculty of Science, University of Isfahan, Isfahan 81746, Iran. meh.yazdi@gmail.com \\ ${ }^{3}$ Department of Geology, Faculty of Science, University of Isfahan, Isfahan 81746, Iran. Bahrami geo@yahoo.com \\ ${ }^{4}$ ISEM, Univ Montpellier, CNRS, EPHE, IRD, Montpellier, France. catherine.girard@umontpellier.fr \\ ${ }^{5}$ Dipartimento di Scienze Biologiche, Geologiche e Ambientali, Alma Mater Studiorum-Università di Bologna, via \\ Zamboni 67, I-40126 Bologna, Italy. claudia.spalletta@unibo.it \\ ${ }^{6}$ Department of Ecology, Institute of Science, High Technology and Environmental Science, Graduate University of \\ Advanced Technology, Kerman, Iran. ameri.paleo@yahoo.com
}

\begin{abstract}
The Givetian to Famennian (Middle-Upper Devonian) Bahram Formation deposits (Bondar and Shahzadeh Mohammad sections) in the Kerman region, Central Iran were sampled for conodonts. The conodonts were described, their distribution investigated, and the studied sections were correlated. In the previous conodont-based papers, the age of the Bahram Formation in the Kerman region was from the upper Givetian hermanni Zone to the middle Famennian Uppermost marginifera Zone (Middle to Late Devonian). However, the new results of this study show that the Bondar section spans from the middle Givetian ansatus Zone to the upper Famennian (middle part of the Middle expansa Zone=Bispathodus aculeatus aculeatus Zone) and the Shahzadeh Mohammad section spans from the middle Givetian ansatus Zone to the lower Famennian (Uppermost crepida=Palmatolepis glabra pectinata) Zone. In both of the studied sections, the Givetian/Frasnian boundary has been identified by the first occurrence of
\end{abstract}


Ancyrodella rotundiloba pristina, but there is no obvious (sedimentological or biostratigraphic)

evidence to define the Frasnian/Famennian boundary.

Keywords: conodont, Devonian, Givetian, Frasnian, Famennian, biostratigraphy.

\section{Introduction}

Iran was situated at the northern margin of Gondwana, at $20^{\circ}-25^{\circ} \mathrm{S}$ of the equator during the Devonian (Wendt et al. 2002) and has been separated from the Gondwanan-Arabian plate since the late Palaeozoic (Berberian and King 1981). In Central Iran, Devonian sedimentary rocks are widely exposed in the Tabas and Kerman regions. Devonian to Lower Carboniferous deposits of Central Iran are divided into the following formations (and their local equivalents/synonyms): Padeha (red siliciclastics; Lower to lower Middle Devonian), Sibzar (only patchily developed; dolomite; (upper Middle Devonian), Bahram (limestones; upper Middle and Upper Devonian), Sardar (siliciclastics, mainly conglomerates; Lower Carboniferous) and Hutk Formation (carbonate platform facies; Lower Carboniferous) (Wendt et al. 2002). Among them, the Bahram Formation is of particular interest because this formation has the best potential for studying Devonian paleontological and depositional records in Central Iran. The Bahram Formation was deposited during the late Middle to Late Devonian (Givetian- Famennian) in Central Iran as a segment of the northern margin of Gondwana (Wendt et al. 2002; Bahrami et al. 2015). Deposits of the Bahram Formation comprise 100 to over $450 \mathrm{~m}$ of thick successions of marine limestones (from shallow open marine and temporarily restricted conditions), with shale siliciclastic layers interbedded. The latter originated from local clastic influx from nearby eroded land areas (Wendt et al. 2002; Ghorbani 2019). Generally, the limestones of the Bahram Formation are very fossiliferous and contain conodonts, brachiopods, stromatoporoids, crinoids, tentaculitids, 
bryozoans, tabulate and rugose corals, trilobites and rare molluscs. Deposits of the Bahram Formation or their equivalents were observed (if not eroded before the Permian transgression) all over northern, central and eastern Iran (Wendt et al. 2002). Bahram Formation is equivalent with Kereshk Formation (Davaran Mountains, NW of Kerman), Rahdar Formation (Kalmard area, W Tabas), Khoshyeilagh Formation (eastern Elburz, N Iran), Geirud Formation (central Elburz, N Iran), and Ilanqareh Formation (Azarbayjan, NW Iran). Besides, parts of the Zarand Formation (Devonian-Tournaisian), correspond to Bahram Formation. Zarand Formation which is a heterogeneous sequence of mainly red sandstones, quartzites, shales (in some layers grey or black), laminated dolomites, and very rare limestones, was previously mapped as Padeha, Sibzar, Bahram, Shishtu and Sardar formations (Wendt et al. 2002). Wendt et al. (2002) proposed to abandon the term "Shishtu Formation" (Famennian/Lower Tournaisian) because it cannot be clearly distinguished from the Bahram Formation and consequently, it was considered as Bahram Formation. This Formation was deposited under shallow-water conditions, and it is difficult to find the pelagic conodonts generally used in the standard Devonian conodont zonations (Ziegler and Sandberg 1990; Spalletta et al. 2017, etc). There is a long stratigraphic gap between the Devonian deposits and the oldest rocks in Central Iran. In the Kerman region, the Devonian strata directly overlay the oldest sequence with different contact and it is difficult to recognize this contact. Devonian succession overlaid rocks attributed to the early Cambrian in the SareAshk (Bahrami et al. 2014), Shahzadeh Mohammad (this study), Hur (Ahmadi et al. 2012), Hojedk (Gholamalian \& Kebriaei 2008) and Shams-Abad (Bahrami et al. 2011) sections, overlaid Ordovician rocks in the Banestan and Rizu sections (Wendt et al. 2002, 2005), overlaid rocks attributed to the Early Silurian in Shabjareh and Sultan Abad sections (Wendt et al. 2002, 2005). 
The main objectives of this study are to improve the biostratigraphic data of the Bahram Formation, by discriminating the recognized conodont fauna, and to discuss the stratigraphic range of the Bahram Formation in Bondar and Shahzadeh Mohammad sections in the north of Kerman (northern margin of Gondwana). Besides, the studied sections will be compared with other sections of the Bahram Formation in the Kerman region.

\section{Previous Work}

The first reports on the presence of Devonian and Lower Carboniferous deposits in Iran were published by Viquesnel (1850) and Loftus (1855). Huckriede et al. (1962) described the regional geology and stratigraphy of the Kerman to Saghand areas from Central Iran. Wendt et al. (1997, 2002) provided a more comprehensive overview of stratigraphy, facies, and paleogeography of Central Iran. Because of its abundant and diverse biota as well as its position in the northern margin of Gondwana, the Bahram Formation moved into the focus of scientific researches during the last 20 years. The macrofossil fauna of Bahram Formation was intensively studied; trilobites (Morzadec et al. 2002), crinoids (Webster, 2003), fish remains (Janvier, 1974; Golshani et al., 1972 and Golshani and Lapparent, 1973), brachiopods (Brice, 1999a \& 1999b; Bassett and Dastanpour, 1998), corals (Rohart, 1999), stromatoporoid (Mistiaen, 1999). The palynomorphs (acritarchs and miospheres) were studied by Ghavidel Syooki et al. (2011). The conodont faunas have been previously described in some papers (Ahmadi et al. 2012; Bahrami et al. 2011; Bahrami et al. 2014; Gholamalian 2006; Gholamalian and Kebriaei 2008; Nasehi 2018), but not for entire Bahram Formation sequence. Dastanpour (1996) and Dastanpour and Aftabi (2002) worked on the geochemistry and sequence stratigraphy of Devonian strata in Kerman. Hashmie 
et al. (2016) studied the sequence stratigraphy and depositional environments of the Bahram Formation in N Kerman.

\section{Geological setting}

Iran is divided into eight geological provinces; each has its own distinct tectonic and sedimentary history. These geological provinces are (1) Zagros (2) Sanandaj-Sirjan (3) Orumieh-Dokhtar magmatic arc, (4) Central Iran, (5) Alborz, (6) Kopeh Dagh, (7) Lut, (8) Makran accretionary prism (Heydari et al. 2003; Aghanabati 2004). The geology and especially the tectonic structure of Iran are highly influenced by the development and history of the Tethyan region (Alavi 2004; Reichert 2007). Iran represents a mosaic of continental blocks separated from each other by foldand-thrust belts formed during the opening and closure of the Tethyan oceanic basins during three major evolutionary stages (Reichert 2007).

The study area is located in Central Iran province. During the Paleozoic, the Central Iran and Zagros fold belt were part of the northern margin of Gondwana (Berberian and King 1981; Wendt et al. 2002) which during the Devonian period was situated at $20-25^{\circ} \mathrm{S}$ of the equator (Golonka et al. 1994; Wendt et al. 2002). This cratonic area was covered by a large shelf sea and was separated from northern Elburz and Kopet Dagh as part of the southern margin of Laurasia (Turan Plate) by the Palaeo-Tethys (Wendt et al. 2002). Devonian deposits of the studied area are divided into the Padeha and Bahram formations.

\section{Material and methods}

Ninety-five conodont samples (4-5 kg each) have been collected from the Bahram Formation: 40 samples from the Shahzadeh Mohammad section, and 55 samples from the Bondar section. The 
samples were processed with the conventional acetic acid technique. The conodonts were extracted from residues by hand-picking. 66 samples yielded conodonts (29 samples from the Shahzadeh Mohammad section and 37 samples from the Bondar section). 1744 conodonts were collected (Tab. 1, 2). In general, the preservation of the conodont elements is good; however, some specimens are broken or incomplete. Conodonts are stored at the Department of Geology (sample numbers: EUIC), University of Isfahan, I.R. Iran. Repository numbers of the figured specimens are provided in the explanations of plates. Conodont abundance and diversity are low for both studied sections.

\section{Lithostratigraphy}

\section{Bondar section}

The Bondar section is located in a small gorge between the villages of Bondar and Sardar, $8 \mathrm{~km}$ east of Chatroud town and about $43 \mathrm{~km}$ north of Kerman, at geographic coordinates $30^{\circ} 49^{\prime} 38^{\prime \prime} \mathrm{N}$, $57^{\circ} 02^{\prime} 04^{\prime \prime}$ E, where a relatively complete succession from Lower Devonian (Padeha Formation) to Permian rocks (Jamal Formation) is exposed (Fig.1).

The section is mapped in the Zarand geological Map (scale, 1: 100,000; Vahdati Daneshmand 1995). Several faults have disrupted the rock sequences of the area, resulting in Paleozoic sediments being found adjacent to Triassic and Tertiary deposits. In the Bondar area, the Devonian is represented by more than $750 \mathrm{~m}$ of sediments, including deposits of the Padeha and Bahram formations (Lower-Upper Devonian).

The oldest exposed rock unit in the Bondar section is represented by red shale, sandstones, and white quartzite of the Padeha Formation (Lower Devonian) which is disconformably overlaid by the Bahram Formation, which consists of $458 \mathrm{~m}$ of terrigenous sediments, carbonate and biostromal limestones. 
The Bahram Formation in the studied area can be divided into seven sedimentological packages. They are from base to top as follows:

1) Red sandstone, purple shale, and white quartzites with cross-bedding (from 0 to 22 meters).

2) Sandy limestone, dolomitic limestone, limestone with brachiopods, crinoids, and bryozoans (from 22 to 94 meters).

3) Biostromal limestone with rugose and tabulate corals, stromatoporoid, brachiopods, crinoids, and bryozoans (from 94 to 125 meters).

4) White quartzite, siltstone, and silty calcareous mudstones, with an interbedded red-brown sandy limestone with numerous fish-remains (from 125 to 224 meters).

5) Sandy limestone, dolomitic limestone, limestone with brachiopods, crinoids, and bryozoans (from 224 to 373 meters).

6) White to yellow sandstone, black shale, siltstone, and white quartzite, with cross-bedding (from 373 to 392 meters).

7) Dolomite, oolitic limestone, and limestone with brachiopods, crinoids, and bryozoans (from 392 to 448 meters).

The Bahram Formation is disconformably overlaid by the limestones of the Hutk Formation (Tournaisian?) (Figs. 2 and 3).

\section{Shahzadeh Mohammad section}

The Shahzadeh Mohammad section is located west of long Bidou gorge, between the villages of Shahzadeh Mohammad and Gerik, $33 \mathrm{~km}$ east of Zarand, at geographic coordinates 30 48'25" N, $56^{\circ} 55^{\prime} 55^{\prime \prime}$ E. In the western flank of the Bidou syncline, an uplift exposed the thickest and most 
complete succession of the Devonian, tectonically packed between Lower Cambrian Daho Formation and the Permian Jamal Formation.

This section is mapped in the Zarand geological Map (scale, 1: 100,000; Vahdati Daneshmand 1995), and limited by the Darcinoie fault on the west (Fig. 1).

The oldest unit in this area is the Dahu Formation (Lower Cambrian) composed of a thick succession of red sandstones and red shales disconformably overlaid by Devonian Padeha Formation (Wendt et al. 2002). In this area, more than $400 \mathrm{~m}$ of Devonian sediments, including the Padeha and Bahram formations, are exposed. The Padeha Formation consists of more than $100 \mathrm{~m}$ of arkosic sandstone, dolomite, and red shale with a few limestone beds.

The Bahram Formation is about $300 \mathrm{~m}$ thick and can be subdivided into nine sedimentological packages from bottom to top. (Fig. 4):

1) Sandstone, sandy limestone, limestone, dolo limestone with brachiopods, crinoids, and bryozoans (from 0 to 38 meters).

2) Biostromal limestone with rugose and tabulate corals, stromatoporoid, brachiopods, crinoids, and bryozoans, which is twice as thick (near 63m) and better developed than at the Bondar section (from 38 to 100 meters).

3) Sandy limestone, limestone, dolo limestone with brachiopods, crinoids, bryozoans, and tentaculitids (from 100 to 133 meters).

4) White to yellow sandstone (from 133 to 138 meters).

5) Black shale (from 138 to 149 meters).

6) Siltstone and white quartzite, with cross-bedding (from 149 to 179 meters).

7) Dolomite, oolitic limestone, and limestone with brachiopods, crinoids, bryozoans (from 179 to 261 meters). 
8) Black shale (from 261 to 270 meters).

9) Limestone, dolo limestone with brachiopods, crinoids, bryozoans (from 270 to 293 meters).

The upper boundary of the Bahram Formation is disconformably overlaid by an erosional surface and a thin paleo-soil horizon at the base of Jamal Formation (Permian) (Fig. 2i).

\section{Biostratigraphy}

1744 conodonts were collected (Tabs. 1, 2). 54 taxa belonging to eight genera (Ancyrodella, Bispathodus, Clydagnathus, Icriodus, Pandorinellina, Pelekysgnathus, Polygnathus, and Pseudopolygnathus) were determined. The color alteration of conodonts is beyond the diagenetic stage (CAI 4 - 4.5), which is included in the anchizone (range of value from 4 to 5.49).

Here we follow Givetian zonations presented in Bultynck (1987), Narckiewicz and Bultynck (2007, 2010) and Liao \& Valenzuela-Ríos (2017). The Frasnian Zones of Klapper (1989), which were updated by Klapper and Kirchgasser (2016), as well as their correlation to Ziegler and Sandberg (1990) zonations are the base of Frasnian biostratigraphy. Famennian biostratigraphy was done based on the Ziegler and Sandberg (1990) and Spalletta et al. (2017) zonations.

\section{Bondar section}

A total of 789 conodont elements recorded in the Bondar section lead discriminate of the following biostratigraphic intervals (Fig. 3; Tab. 1).

\section{ansatus Zone}

The lower limit of this interval is recognized by the first appearance of Polygnathus ansatus in sample B1. The first occurrence of Polygnathus ansatus is at the base of the ansatus Zone 
(Bultynck 1987; Narkiewicz \& Bultynck 2007, 2010; Liao \& Valenzuela-Rios 2017). The upper limit can be identified by the last presence of Icriodus lindensis. The last occurrence of Icriodus lindensis is within the lower part of the ansatus Zone (Narkiewicz \& Bultynck 2007). Other associated species are Icriodus arkonensis walliserianus, I. brevis, I. difficilis, I. cf. lilliputensis, Polygnathus cf. denisbriceae, P. rhenanus, P. varcus, and P. xylus.

\section{Upper hermanni to lower part of the Lower falsiovalis (norrisi) zones}

This interval can be recognized by the entry of Icriodus subterminus for the base in sample B7 and the entry of Ancyrodella rotundiloba pristina, which identifies the base of the next biozone. The first occurrence of Icriodus subterminus is in the uppermost part of the Upper hermanni Zone, (Narkiewicz \& Bultynck 2010). Other associated species are Icriodus brevis, Icriodus difficilis, I. excavatus, Polygnathus dubius, and P. xylus.

\section{Upper part of the Lower falsiovalis (Frasnian Zone 1) to middle part of the Upper falsiovalis zones}

The start of this interval is defined by the entry of Ancyrodella rotundiloba pristina in sample B11. According to Klapper and Kirchgasser (2016), the entry of Ancyrodella rotundiloba pristina indicates the base of the Frasnian; the first occurrence of Ancyrodella rotundiloba pristina is within the Lower falsiovalis Zone (Ji \& Ziegler 1993). The top of this interval is identified by the occurrence of Polygnathus ovatinodosus in sample B12. The range of Polygnathus ovatinodosus was reported as high as the top of the Lowermost asymmetricus Zone by Klapper and Ziegler (1979) which is equivalent to the middle part of the Upper falsiovalis 
Zone. Other associated species are Icriodus difficilis, I. excavatus, I. subterminus, Polygnathus alatus, $P$. praepolitus, $P$. webbi and P. xylus.

Upper part of the Upper falsiovalis (lower part of Frasnian Zone 3) to the transitans (Frasnian Zone 4) zones

The base of this interval can be recognized by the last occurrence of Polygnathus ovatinodosus at the top of the previous interval sample B12. The top of this interval is identified by the entry of Polygnathus zinaidae in sample B18, which has its first occurrence within the punctata Zone (Ovnatanova \& Kononova 2001). Other associated species are Icriodus excavatus, I. subterminus, Polygnathus alatus, and P. webbi.

\section{Upper hassi (Frasnian Zone 9 and 10) to upper part of the Lower rhenana (lower part of} Frasnian Zone 12) zones

The entry of Polygnathus politus in sample B19, which ranges from the Upper hassi to the linguiformis zones (Narkiewicz and Narkiewicz 2008), define the base of this interval. The upper limit can be identified by the last presence of Icriodus cedarensis and Polygnathus praepolitus in sample B32. The last occurrence of Icriodus cedarensis is within the lower part of Frasnian Zone 12 (Narkiewicz \& Bultynck 2010). Likewise, the last occurrence of Polygnathus praepolitus is within the lower part of Frasnian Zone 12 (Ovnatanova \& Kononova 2001). Associated species are Icriodus excavatus, I. expansus, I. subterminus, Polygnathus aequalis, P. alatus, $P$. aspelundi, $P$. seraphimae, $P$. webbi and $P$. zinaidae. 
Uppermost part of the Lower rhenana (middle part of Frasnian Zone 12) to Upper rhenana (middle part of Frasnian Zone 13) zones

This interval is limited between the last occurrence of Icriodus cedarensis and Polygnathus praepolitus for the base in sample B32 and the last occurrence of $I$. excavatus in sample B34 for the top. According to Gholamalian and Kebriaei (2008), Icriodus excavatus became extinct in the Upper rhenana Zone. Polygnathus angustidiscus is associated species.

\section{Linguiformis (Frasnian Zone 13b) to Palmatolepis triangularis (Lower triangularis) zones}

The base of this interval is characterized by the last occurrence of I. excavatus at the top of the previous interval and the top is coincident with the base of the next one by the first appearance of Pelekysgnathus inclinatus and Icriodus cornutus. Icriodus alternatus alternatus, I. iowaensis iowaensis, and Polygnathus angustidiscus are associated species.

Palmatolepis delicatula platys (Middle triangularis) to Pseudopolygnathus granulosus (Upper trachytera) zones

The base is defined by the first appearance of Pelekysgnathus inclinatus and Icriodus cornutus in sample B41, and the top of this interval is corresponding with the base of the next interval. The lowest occurrence of both Icriodus cornutus and Pelekysgnathus inclinatus is within the Middle triangularis Zone (Sandberg and Dreesen 1984; Huang and Gong 2016). Other associated species is Polygnathus brevilaminus.

Polygnathus styriacus (Lower postera) to Palmatolepis gracilis expansa (Lower expansa) zones 
The base is recognized by the occurrence of Polygnathus communis collinsoni in sample B44, which has its first occurrence within the Lower postera Zone (Druce 1969). The top of this interval is coincident with the base of the next interval. Associated species are: Bispathodus stabilis vulgaris, Pandorinellina $\mathrm{cf}$. insita sensu Sandberg and Ziegler (1979), Pelekysgnathus inclinatus, Polygnathus communis communis, and P. com. dentatus.

\section{Bispathodus aculeatus aculeatus (Lower part of the Middle expansa) Zone}

The base is recognized by the first occurrence of Clydagnathus plumulus and Bispathodus aculeatus anteposicornis in sample B49, and the top is coincident with the last occurrence of Clydagnathus tragelehni in sample B50.

The first occurrence of Clydagnathus plumulus is at the base of the Middle expansa Zone (Hartenfels 2011). The first occurrence of Bispathodus aculeatus anteposicornis is within the Middle expansa Zone (Ziegler et al. 1974). The last occurrence of Clydagnathus tragelehni is in the middle part of the Middle expansa Zone (Hartenfels 2011). Associated species are Clydagnathus ormistoni, Pseudopolygnathus primus.

\section{Shahzadeh Mohammad section}

The Shahzadeh Mohammad section yielded 955 conodont elements enabling discrimination of the following biozonal intervals (Fig. 4; Table 2).

\section{ansatus to Lower hermanni zones}

The lower boundary of this interval is recognized with the lowest appearance of Polygnathus ansatus in sample Sh7 that is the zonal index (Ziegler et al. 1976). According to Narkiewicz \& 
Bultynck $(2007,2010)$ and Aboussalam (2003), this species ranges from the base of the ansatus Zone to the Upper hermanni Zone; but Bardashev (1992) extended its upper range to the Lower disparilis Zone. This upper range is confirmed by Gouwy et al. (2016).

The upper limit can be identified by the first presence of Icriodus subterminus at the base of the next interval.

Other associated species are Icriodus arkonensis arkonensis, I. brevis, I. difficilis, Polygnathus varcus and P. xylus.

\section{Upper hermanni to norrisi zones}

The lower limit of this interval is defined by the entry of Icriodus subterminus in sample Sh9, its upper boundary by the entry of Ancyrodella rotundiloba pristina at the base of Frasnian, in sample Sh12 (Fig. 2g). The occurrence of Icriodus subterminus indicates the upper part of the Upper hermanni Zone according to Narkiewicz and Bultynck (2010). Other associated species are Icriodus brevis, Polygnathus alatus, P. ovatinodosus, P. varcus, and P. xylus.

\section{Upper part of the Lower falsiovalis (Frasnian Zone 1) to Upper falsiovalis (Frasnian Zone}

\section{3) zones}

The lower limit of this interval is identified by the entry of Ancyrodella rotundiloba pristina in level Sh12, its upper limit by the entry of Polygnathus aequalis in sample Sh13. The entry of Ancyrodella rotundiloba pristina defines the upper part of the Lower falsiovalis Zone, equivalent

to the base of the Frasnian Zone 1. Other associated species are Icriodus expansus, I. symmetricus, I. tafilaltensis, Polygnathus alatus, P. dubius, P. praepolitus, and P. webbi. 


\section{transitans (Frasnian Zone 4) Zone}

The lower boundary is recognized by the lowest occurrence of Polygnathus aequalis in sample Sh13, which ranges from the transitans Zone to the Lower rhenana Zone (Barskov et al. 1991; Ji \& Ziegler 1993). Gholamalian (2007) extended the range of this species to the linguiformis Zone. The upper boundary is defined by the lowest occurrence of Polygnathus seraphimae and Polygnathus zinaidae in sample Sh18. Other associated species are: Ancyrodella sp., Icriodus difficilis, I. subterminus, I. symmetricus, Polygnathus alatus, P. praepolitus, and P. webbi.

\section{punctata (Frasnian Zone 5 and 6) to Upper hassi (Frasnian Zone 9 and 10) zones}

This interval is limited by the lowest occurrence of Polygnathus seraphimae and Polygnathus zinaidae in level Sh18, and the highest occurrence of Icriodus expansus in sample Sh24, which, according to Bultynck (2003), may reach the Upper hassi Zone. This species reaches the end of Upper Semiluki Regional Stage in Ovnatanova \& Kononova 2001, which corresponds to the punctata-Late hassi zones of the Standard Conodont Zonation (Ovnatanova \& Kononova 2008, 2020). The first occurrences of Polygnathus seraphimae and Polygnathus zinaidae are in the

punctata Zone (Ovnatanova \& Kononova 2001). Other associated species are Icriodus excavatus, Polygnathus alatus, and P. praepolitus.

\section{Lower rhenana (upper part of Frasnian Zone 11-lower part of Frasnian Zone 12) to Upper rhenana (upper part of Frasnian Zone 12 to Frasnian Zone 13a) zones}

The lower limit is indicated by the entry of Icriodus iowaensis iowaensis in sample Sh25, and the upper limit is marked by the entry of Polygnathus brevilaminus at the base of the next interval. The lowest occurrence of Icriodus iowaensis iowaensis is within the Lower rhenana Zone 
(Bahrami et al. 2013). Other associated species are Polygnathus aspelundi, P. praepolitus, P. cf. seraphimae, and P. webbi.

\section{linguiformis (Frasnian Zone 13b) Zone}

The base of this interval can be identified by the first occurrence of Polygnathus brevilaminus in sample Sh32, which ranges from within the linguiformis (Schülke 1995) to the Upper trachytera (Hartenfels 2011) zones; the upper limit is recognized by the unique occurrence of Polygnathus krestovnikovi in sample Sh33, which, according to Narkiewicz and Narkiewicz (2008) and Ovnatanova and Kononova (2008), became extinct within the linguiformis Zone. Other associated species are Icriodus alternatus alternatus, I. iowaensis iowaensis, Polygnathus aequalis and $P$. angustidiscus.

\section{Palmatolepis delicatula platys (Middle triangularis) to Palmatolepis crepida (Lower crepida) zones}

The lower boundary is characterized by the appearance of Pelekysgnathus inclinatus and Icriodus cornutus in sample Sh35, and the upper boundary is defined by the entry of Polygnathus semicostatus at the base of the next interval. The first occurrence of both Icriodus cornutus and Pelekysgnathus inclinatus is within the Pa. delicatula platys (Middle triangularis) Zone (Sandberg and Dreesen 1984; Huang and Gong 2016). Other associated species are Icriodus alternatus alternatus, I. iowaensis iowaensis, Polygnathus angustidiscus, P. brevilaminus.

Palmatolepis termini (Middle crepida) to Palmatolepis glabra pectinata (Uppermost crepida) zones 
This interval is limited by the first occurrence of Polygnathus semicostatus in sample Sh38, that ranges from the termini (=Middle crepida) to the Bispathodus ultimus (Upper expansa) zones (Ji \& Ziegler 1993) and the last occurrence of Icriodus alternatus alternatus and Polygnathus procerus in sample Sh40, which both have their last occurrence within the Pa. glabra pectinata (Uppermost crepida) Zone (Bultynck 2003; Corradini 2003; Spalletta et al. 2017). Other associated species are Icriodus cornutus, I. iowaensis iowaensis, Pelekysgnathus inclinatus, Pel. serradentatus and Polygnathus brevilaminus.

\section{Discussion and Conclusions}

The Bondar and Shahzadeh Mohammad sections as the most complete successions of the Bahram Formation in the Kerman region were studied based on the conodont fauna. This research provides new data from the northern margin of Gondwana. This work represents a good example of the regional correlation of the Devonian sequences from the Kerman region (Central Iran) where deposits are characterized by different paleoconditions and sedimentation pulses. The main results are discussed and interpreted below.

Due to synsedimentary tectonic movements, the Bahram Formation in Kerman was yielded different thicknesses and sedimentation pattern, which are visible in nearby sections. For example, the Sardar section (Gholamalian et al. 2015) and the Bondar section have been measured only a few km apart, but their age and thicknesses differ significantly. In the Sardar section, the linguiformis Zone shows about $25 \mathrm{~m}$, whereas in the Bondar section the same stratigraphic interval is documented by about $90 \mathrm{~m}$ of rocks.

One of the main features of the Bahram Formation is biostroms that well developed in both of the studied sections. The age of biostroms are different and they are occurred within or between 
the different biozones in different sections: Lower to Upper falsiovalis zones in the Baghin (Gholamalian et al. 2013; Gholamalian et al. 2011) and Hojedk (Gholamalian \& Kebriaei 2008) sections, the upper part of the Upper falsiovalis to the transitans zones in the Bondar section and transitans Zone in the Shahzadeh Mohammad section (this study), transitans to punctata zones in the Sardar section (Gholamalian et al. 2015), transitans to Upper hassi zones in the Sar-eAshk section (Bahrami et al. 2014), Upper hassi to jamieae zones in the Gerik section (Gholamalian et al. 2014), Early hassi to jamieae zones in the Hutk section (Gholamalian 2006), and Upper rhenana to linguiformis zones in the Hur section (Ahmadi et al. 2012). This diachronism is more likely due to the close relationship of the corals to the paleoecological conditions. So that the favorable conditions for coral flourishing were provided at different ages. The thickness of the Bahram Formation is very different in the Kerman region; it ranges from $100 \mathrm{~m}$ in the Horik section to over $450 \mathrm{~m}$ in the Bondar section. The variable thickness of the Bahram depends not only on the rate of subsidence and sediment accumulation but also on the level of the pre-Permian erosion (Wendt et al. 2002). In the Hur, Sar-e-Ashk and Baghin sections tectonic and erosion were maximum so that in these sections the higher Devonian biozone is represented by the Frasnian linguiformis Zone, whereas, in Bondar, Sardar, Hutk, Shahzadeh Mohammad and Shams Abad sections tectonic and erosion were minimum, the top of the formation reached respectively the Famennian Bi. aculeatus aculeatus - Bi. costatus (Middle expansa), Pseudopolygnathus granulosus (Upper trachytera), Pa. glabra prima (Upper crepida), Pa. glabra pectinata (Uppermost crepida) and Scaphignathus velifer velifer (Uppermost marginifera) zones (Fig. 5).

The oldest biozones reported from the Bahram Formation by the previous researchers belong to the upper Givetian hermanni Zone. Our analysis resulted in the identification of older biozones. 
So, the middle Givetian (ansatus Zone) recorded for the first time by this study. Besides, upper Famennian (top of Bi. aculeatus aculeatus- base of Bi. costatus Zones = middle part of Middle expansa Zone), which is recognized in the Bondar section, is the youngest age reported for the Bahram Formation, in the Kerman region. The above-mentioned new results strongly confirm that the Bondar and Shahzadeh Mohammad stratigraphic sections are the most complete successions of the Bahram Formation in the Kerman region. The Givetian Frasnian boundary is identified by the entry of Ancyrodella rotundiloba pristina in samples B11 and Sh12 in the Bondar and Shahzadeh Mohammad sections respectively.

\section{Acknowledgements}

The authors are thankful to Ebrahim Mohammadi and Hossein Zamani for helping in the sampling of the sections. Ebrahim Mohammadi provided useful comments on an early version of the manuscript. Raimund Feist is gratefully acknowledged for his special attention. Carlo Corradini is gratefully appreciated for his help in taxonomic identifications. We thank both reviewers Jau-Chyn Liao and Jose I. Valenzuela-Rios; their constructive comments, criticisms, and suggestions significantly improved the quality of this paper. The authors are grateful to the Vice Chancellor for Research and Technology at University of Isfahan for financial and logistic supports. This is publication ISEM 2020-225.

\section{REFERENCES}

- Aboussalam ZS. 2003. Das" Taghanic-Event" im hoheren Mitteldevon von West-Europa und Marokko. Munstersche Forschungen zur Geologie und Palaontologie. 97:1-332.

- Aghanabati A. 2004. Geology of Iran. Geological Survey of Iran publication. 558p.

- Ahmadi T, Dastanpour M, Vaziri MR. 2012. Upper Frasnian (Upper Devonian) Polygnathus And Icriodus Conodonts From The Bahram Formation, Hur Section, Kerman Province, Southeastern 
Iran. Rivista Italiana di Paleontologia e Stratigrafia (Research In Paleontology and Stratigraphy). 118(2).

- Alavi M. 2004. Regional stratigraphy of the Zagros fold-thrust belt of Iran and its proforeland evolution. American journal of science. 304(1):1-20.

- Bahrami A, Corradini C, Over DJ, Yazdi M. 2013. Conodont biostratigraphy of the upper Frasnian-lower Famennian transitional deposits in the Shotori Range, Tabas area, Central-East Iran Microplate. Bulletin of Geosciences. 88(2):369-388.

- Bahrami A, Gholamalian H, Corradini C, Yazdi M. 2011. Upper Devonian conodont biostratigraphy of Shams Abad section, Kerman Province, Iran. Rivista Italiana di Paleontologia e Stratigrafia (Research In Paleontology and Stratigraphy). 117(2):199-209.

- Bahrami A, Königshof P, Boncheva I, Tabatabaei MS, Yazdi M, Safari Z. 2015. Middle Devonian (Givetian) conodonts from the northern margin of Gondwana (Soh and Natanz regions, north-west Isfahan, Central Iran): biostratigraphy and palaeoenvironmental implications. Palaeobiodiversity and Palaeoenvironments. 95(4):555-577.

- Bahrami A, Zamani F, Corradini C, Yazdi M, Ameri H. 2014. Late Devonian (Frasnian) conodonts from the Bahram Formation in the Sar-e-Ashk Section, Kerman Province, Central-East Iran Microplate. Bollettino della Società Paleontologica Italiana. 53(3):179-188.

- Bardashev I. 1992. Conodont stratigraphy of Middle Asian Middle Devonian. Courier Forschungsinstitut Senckenberg. 154:31-83.

- Barskov I, Vorontsova T, Kononova L, Kuzmin A. 1991. Index conodonts of the Devonian and Early Carboniferous. Moscow University, Moscow. 183 pp.

- Bassett M, Dastanpour M. 1998. Frasnian-Famennian brachiopod faunas from south-east Iran: documentation of major extinction, re-diversification and sea level changes. Linesco-IGCP Project 421, Isfahan Meeting, Abstracts. 4.

- Berberian M, King G. 1981. Towards a paleogeography and tectonic evolution of Iran. Canadian journal of earth sciences. 18(2):210-265.

- Brice D. 1999a. New data on systematics of some Famennian spiriferid brachiopods from Afghanistan and Iran. Palaeobiodiversity and Palaeoenvironments. 79(1):281-295.

- Brice D. 1999b. New upper Devonian rhynchonellid and spiriferid Brachiopod taxa from eastern Iran (Kerman province) and central Iran (Soh region). Annales-Societe Geologique Du Nord. 7:71-78.

- Bultynck P. 1987. Pelagic and neritic conodont successions from the Givetian of pre-Sahara Morocco and the Ardennes. Bulletin-Institut royal des sciences naturelles de Belgique Sciences de la terre. 57:149-181.

- Bultynck P. 2003. Devonian icriodontidae: Biostratigraphy, classificación and remarks on paleoecology and dispersal. Revista española de micropaleontología. 35(3):295-314.

- Corradini C. 2003. Late Devonian (Famennian) conodonts from the Corona Mizziu Sections near Villasalto (Sardinia, Italy). Palaeontographia Italica. 89:65-116.

- Dastanpour M. 1996. The Devonian system in Iran: a review. Geological Magazine. 133(02):159170.

- Dastanpour M, Aftabi A. 2002. The cause of biomass extinction at the Frasnian-Famennian boundary, the Kerman province southeastern, central Iran. Journal of Sciences Islamic Republic of Iran. 13(1):45-50.

- Druce EC. 1969. Devonian and Carboniferous conodonts from the Bonaparte Gulf Basin, northern Australia, and their use in international correlation. Bulletin 69, 1-243.

- Ghavidel Syooki M, Sadeghi A, Rouzegar R. 2011. Marine Palynomorphs (Acritarchs) of Late Devonian in Shazadeh Mohammad area, Kerman. Journal of Stratigraphy and Sedimentology Researches. 27(3): 69-82. 
- Gholamalian H. 2006. Biostratigraphy of Late Devonian sequence in Hutk section (north of Kerman) based on conodonts. Geosciences. 15(59):94-101.

- Gholamalian H. 2007. Conodont biostratigraphy of the Frasnian-Famennian boundary in the Esfahan and Tabas areas, Central Iran. Geological Quarterly. 51(4):453-476.

- Gholamalian H, Hairapetian V, Barfehei N, Mangelian S, Faridi P. 2013. Givetian-Frasnian Boundary Conodonts From Kerman Province, Central Iran. Rivista Italiana Di Paleontologia E Stratigrafia. 119(2):133-146.

- Gholamalian H, Hosseini-Nezhad SM, Khosravi Z, Turkzadeh-Mahani I. 2011. Late Devonian conodonts from Baghin section, west of Kerman. Geosciences Scientific Quarterly. 21:165-172. in Persian with English abstract.

- Gholamalian H, Kebriaei M. 2008. Late Devonian conodonts from the Hojedk section, Kerman Province, Southeastern Iran. Rivista Italiana di Paleontologia e Stratigrafia (Research In Paleontology and Stratigraphy). 114(2):179-189.

- Gholamalian H, Sajadi SH, Hassani MJ. 2015. Biostratigraphy of Devonian succession (Bahram Formation) in Sardar section, North of Kerman based on conodonts. Paleontology. 2(2):198-211. in Persian with English abstract

- Gholamalian H, Ghoreishi Maremy S, Parvaneh Nezhad Shirazi M. 2014. Biostratigraphy of Late Devonian Conodonts in Gerik section, Eastern Zarand (Province Kerman ). Geosciences. 23(9):105-114. in Persian with English abstract.

- Ghorbani M. 2019. Lithostratigraphy of Iran. Springer. 274p.

- Golonka J, Ross M, Scotese C. 1994. Phanerozoic paleogeographic and paleoclimatic modeling maps. 1-47.

- Golshani F, Brice D, Corsin P, Janvier P, Lapparent AF. 1972. Discovery of fish fauna and plant remains in Upper Devonian of Bidu in Central Iran. Comptes Rendus Hebdomadaires Des Seances De L Academie Des Sciences Serie D. 275(19): 2103.

- Golshani F, Lapparent AF. 1973. Sur la paléogéographie et la paléobiologie du Dévonien dans la région de Kerman, en Iran.

- Gouwy S, Liao JC, Valenzuela-Rios JI. 2016. Graphic correlation of the upper Eifelian to lower Frasnian (Middle-Upper Devonian) conodont sequences in the Spanish Central Pyrenees and comparison with composite standards from other areas. Palaeontologia Electronica. 19(3):1-18.

- Hartenfels S. 2011. Die globalen Annulata-Events und die Dasberg-Krise (Famennium, Oberdevon) in Europa und Nord-Afrika: hochauflösende Conodonten-Stratigraphie, KarbonatMikrofazies, Paläoökologie und Paläodiversität. Münstersche Forschungen zur Geologie und Paläontologie 105, 17-527.

- Hashmie A, Rostamnejad A, Nikbakht F, Ghorbanie M, Rezaie P, Gholamalian H. 2016. Depositional environments and sequence stratigraphy of the Bahram Formation (middle-late Devonian) in north of Kerman, south-central Iran. Geoscience Frontiers. 7(5):821-834.

- Heydari E, Hassanzadeh J, Wade W, Ghazi A. 2003. Permian-Triassic boundary interval in the Abadeh section of Iran with implications for mass extinction: Part 1-Sedimentology. Palaeogeography, Palaeoclimatology, Palaeoecology. 193(3):405-423.

- Huang C, Gong Y. 2016. Timing and patterns of the Frasnian-Famennian event: Evidences from high-resolution conodont biostratigraphy and event stratigraphy at the Yangdi section, Guangxi, South China. Palaeogeography, palaeoclimatology, palaeoecology. 448:317-338.

- Huckriede R, Kürsten M, Venzlaff H. 1962. Zur Geologie des Gebietes zwischen Kerman und Sagand (Iran). Beihefte zum Geologischen Jahrbuch, v. 51, p. 197.

- Janvier P. 1974. Preliminary report on Late Devonian fishes from central and eastern Iran. Geological Survey of Iran. 31.

- Ji Q, Ziegler W. 1993. The Lali Section: An Excellent Reference Section for Upper-Devonian in South China. Courier Forschungsinstitut Senckenberg. 157: 1-183. 
- Klapper G. 1989. The Montagne Noire Frasnian (Upper Devonian) conodont succession. p. 449468. In N. J. McGhee, A. F. Embry and D. J. Glass (eds), Devonian of the World, vol. III: Paleontology, Paleoecology and Biostratigraphy. Canadian Society of Petroleum Geologists Memoir 14(3):449-468.

- Klapper G, Kirchgasser WT. 2016. Frasnian Late Devonian conodont biostratigraphy in New York: graphic correlation and taxonomy. Journal of Paleontology. 90(3):525-554.

- Klapper G, Ziegler W. 1979. Devonian conodont biostratigraphy. Special papers in Palaeontology. 23:199-224.

- Liao JC, Valenzuela-Ríos JI. 2017. Givetian (Middle Devonian) historical bio-and chronostratigraphical subdivision based on conodonts. Lethaia. 50(3):440-446.

- Loftus WK. 1855. On the geology of portions of the Turko-Persian frontier, and of the districts adjoining. Quarterly Journal of the Geological Society. 11(1-2):247-344.

- Mistiaen B. 1999. On some Devonian (Frasnian) stromatoporoids from Kerman province, eastern Iran. Annales-Societe Geologique Du Nord. 7:33-44.

- Morzadec P, Dastanpour M, Wright AJ. 2002. Asteropygine trilobites from the Late Devonian of the Kerman region, Iran. Alcheringa. 26(1):143-149.

- Narkiewicz K, Bultynck P. 2007. Conodont biostratigraphy of shallow marine Givetian deposits from the Radom-Lublin area, SE Poland. Geological Quarterly. 51(4):419-442.

- Narkiewicz K, Bultynck P. 2010. The Upper Givetian (Middle Devonian) subterminus conodont Zone in North America, Europe and North Africa. Journal of Paleontology. 84(4):588-625.

- Narkiewicz K, Narkiewicz M. 2008. The mid-Frasnian subsidence pulse in the Lublin Basin (SE Poland): sedimentary record, conodont biostratigraphy and regional significance. Acta Geologica Polonica. 58(3):287-301.

- Nasehi E. 2018. New biostratigraphical findings on the Padeha Formation based on conodont accumulation in Yazdanshahr, Kerman, Central Iran. Applied ecology and environmental research. 16(2):993-1018.

- Ovnatanova NS, Kononova LudI. 2001. Conodonts and Upper Devonian (Frasnian) Biostratigraphy-of Central Regions of Russian Platform. Courier Forschungsinstitut Senckenberg. 233:1-115.

- Ovnatanova NS, Kononova LudI. 2008. Frasnian conodonts from the eastern Russian Platform. Paleontological Journal. 42(10):997-1166.

- Ovnatanova NS, Kononova LudI. 2020. Taxonomic problems of some zonal species of the genus Palmatolepis and the correlation of the Frasnian of the East European Platform with conodont zonations. Acta Geologica Polonica. 70(1):107-124.

- Reichert J. 2007. A metallogenetic model for carbonate-hosted non-sulphide zinc deposits based on observations of Mehdi Abad and Irankuh, Central and Southwestern Iran. Martin-LutherUniversität Halle-Wittenberg.

- Rogers FS. 1998. Conodont biostratigraphy of the Little Cedar and Lower Coralville formations of the Cedar Valley Group (Middle Devonian) of Iowa and significance of a new species of Polygnathus. Journal of Paleontology. 72(4):726-737.

- Rohart JC. 1999. Palaeozoic rugose corals from central and eastern Iran (AF de Lapparent and M. Zahedi collections). Annales-Societe Geologique Du Nord. 7:47-70.

- Sandberg CA, Dreesen R. 1984. Late Devonian icriodontid biofacies models and alternate shallow water conodont zonation, Geological Society of America Special Paper. 196:143-178.

- Sandberg CA, Ziegler W. 1979. Taxonomy and biofacies of important conodonts of Late Devonian styriacus-Zone, United States and Germany. Geologica et Palaeontologica. 13:173-212.

- Schülke I. 1995. Evolutive Prozesse bei Palmatolepis in der frühen Famenne-Stufe (Conodonta, Ober-Devon). Göttinger Arbeiten zur Geologie und Paläontologie, 67, 108 p. 
- Spalletta C, Perri MC, Over DJ, Corradini C. 2017. Famennian (Upper Devonian) conodont zonation: revised global standard. Bull. Geosci. 92 (1), 31-57.

- Vahdati Daneshmand F. 1995. Geology of Zarand: Geology survey of Iran.

- Viquesnel A. 1850. Notice sur la collection de roches recuillie en Asie par feu Hommaire de Hell, et sur les divers travaux exécutés pendant le cours de son voyage. Bulletin de la Societé Géologique de France, Série. 2(7):491-514.

- Webster G. 2003. Bibliography and index of Paleozoic crinoids, coronates, and hemistreptocrinoids. Geological Society of America Special Paper. 363:1758-1999.

- Wendt J, Hayer J, Karimi Bavandpur AK. 1997. Stratigraphy and depositional environment of Devonian sediments in northeast and east-central Iran. Neues Jahrbuch fur Geologie und Palaontologie Abhandlungen. 206:277-322.

- Wendt J, Kaufmann B, Belka Z, Farsan N, Bavandpur AK. 2005. Devonian/Lower Carboniferous stratigraphy, facies patterns and palaeogeography of Iran Part II. Northern and central Iran. Acta Geologica Polonica. 55(1):31-97.

- Wendt J, Kaufmann B, Bełka Z, Farsan N, Bavandpur AK. 2002. Devonian/lower carboniferous stratigraphy, facies patterns and palaeogeography of Iran. Part I. Southeastern Iran. Acta Geologica Polonica. 52(2):129-168.

- Ziegler W, Klapper G, Johnson JG. 1976. Redefinition and subdivision of the varcus-Zone (Conodonts, Middle-? Upper Devonian in Europe and North America. Geologica et Palaeontologica. 10:109-140.

- Ziegler W, Sandberg CA. 1990. The Late Devonian standard conodont zonation. Courier Forschungsinstitut Senckenberg.121:1-115.

- Ziegler W, Sandberg CA, Austin R. 1974. Revision of Bispathodus group (Conodonta) in the Upper Devonian and Lower Carboniferous. Geologica et Palaeontologica. 8:97-112. 


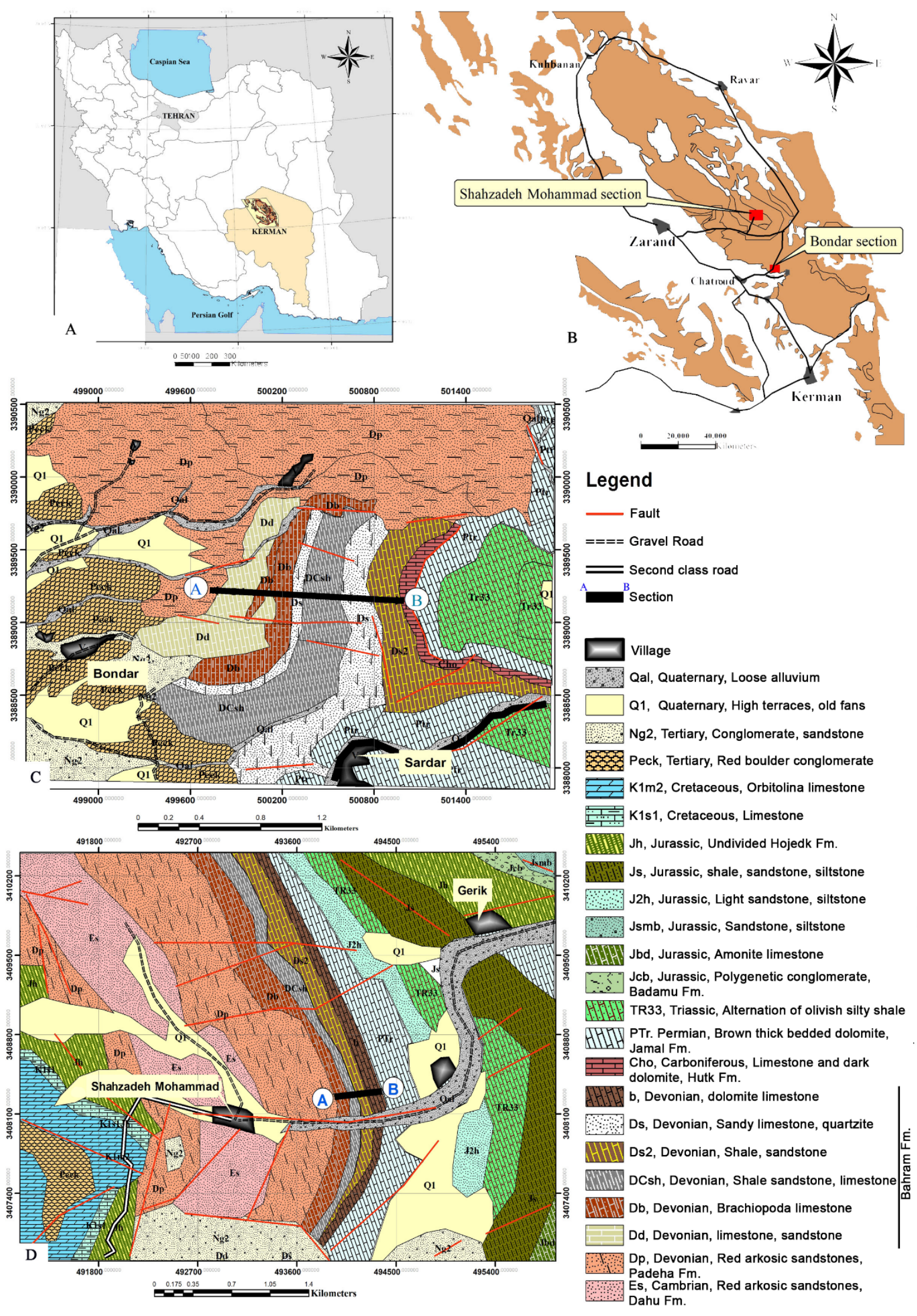


Fig. 1: A) Location of the studied sections in Central Iran. B) Location of the studied sections in Kerman. C) A geological map showing the Bondar section (modified after Vahdati Daneshmand 1995). D) A geological map showing the Shahzadeh Mohammad section (modified after Vahdati Daneshmand 1995).
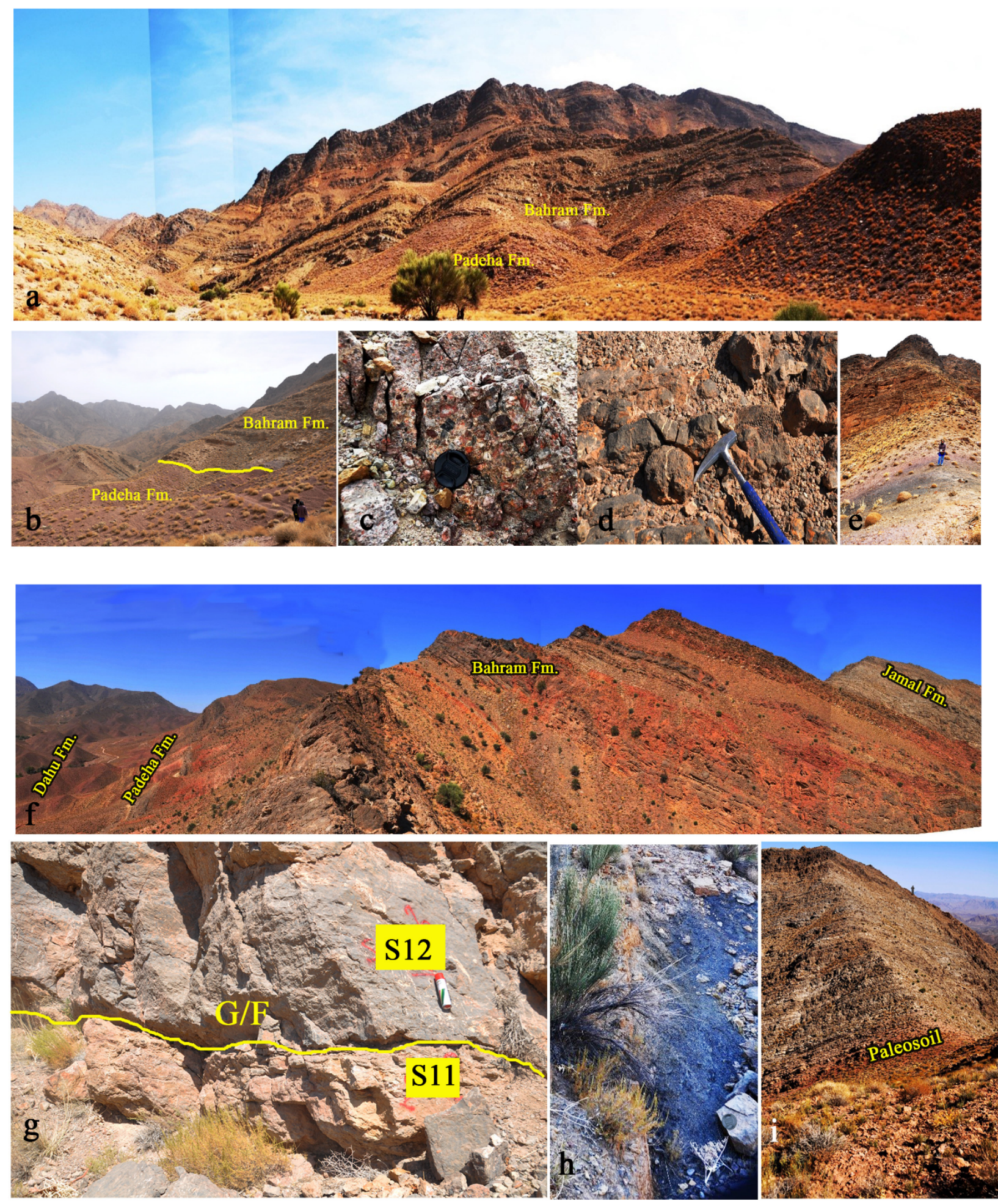
Fig. 2: Selected views of the studied sections. a) Panoramic view of the Bondar section. b) The boundary between the Padeha and the Bahram formations at the Bondar section. c) Close-up view of the basal conglomerate of the Bahram Formation at the Bondar section. d) Close-up view of a Hexagonarid coral in the lower part of the Bahram Formation at the Bondar section. e) Black shale in the upper part of the Bondar section (between beds B41 and B42, see Fig. 4). f) Panoramic view of the Paleozoic succession, from the Cambrian Dahu Formation, through the Devonian Padeha and Bahram formations, to the Permian Jamal Formation at the Shahzadeh Mohammad section. g) Close-up view of the Givetian-Frasnian boundary. h) Black shale in the middle part of the Shahzadeh Mohammad section (between beds Sh22 and Sh23, see Fig. 5). i) View of the paleosoil between the Devonian Bahram Formation and the Permian Jamal Formation. 


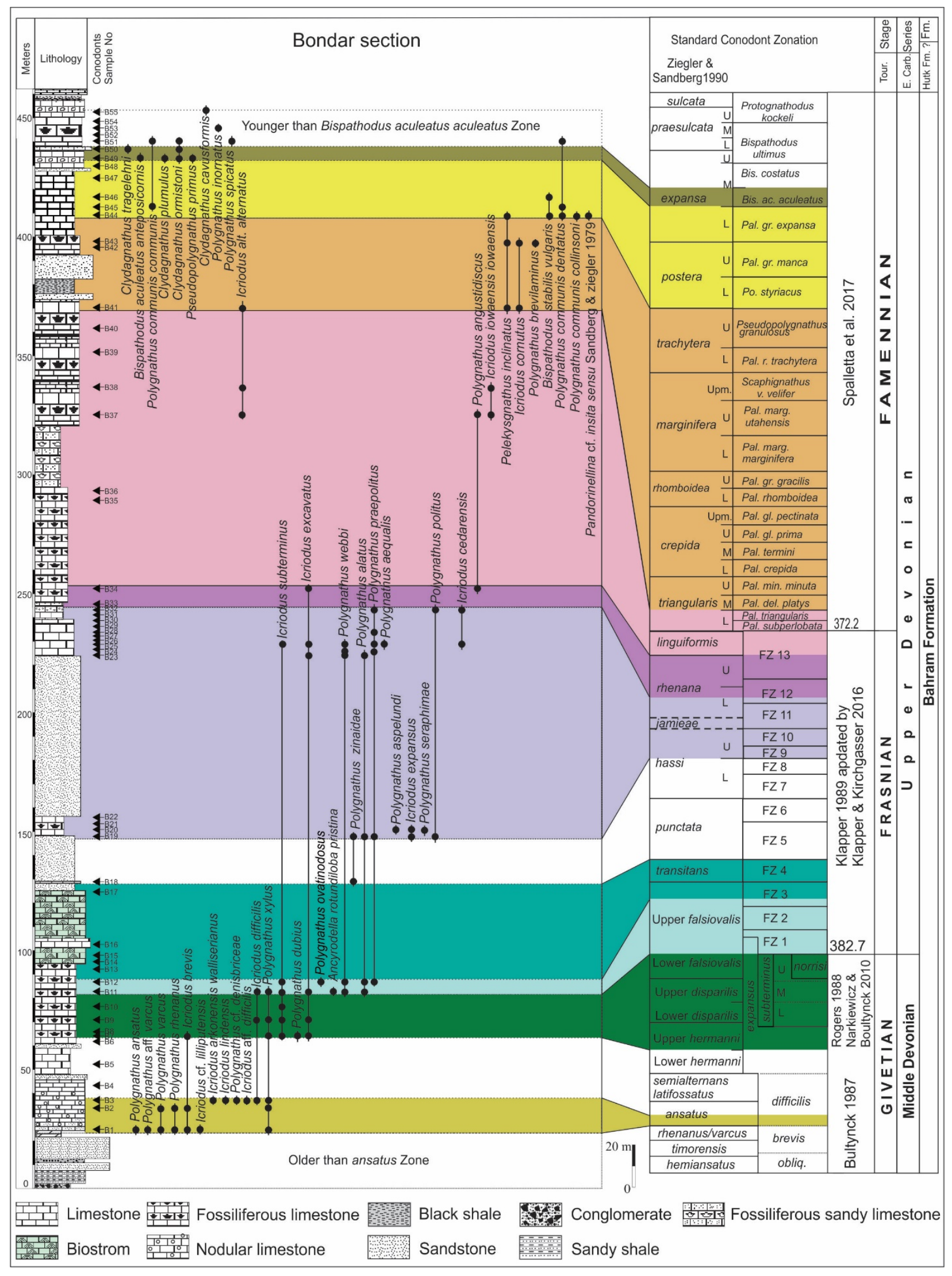


Fig. 3: Stratigraphic log, samples position, conodont occurrences and biozonation of the Bondar section. Abbreviations: L: Lower M: Middle, U: Upper, Upm: Uppermost, FZ are from Klapper and Kirchgasser (2016), Bis: Bispathodus, po: Polygnathus, Pal: Palmatolepis, obliq: obliquimarginatus del: delicatula, min: minuta, gl: glabra, gr: gracilis, marg: marginifera, v: velifer, ac: aculeatus.

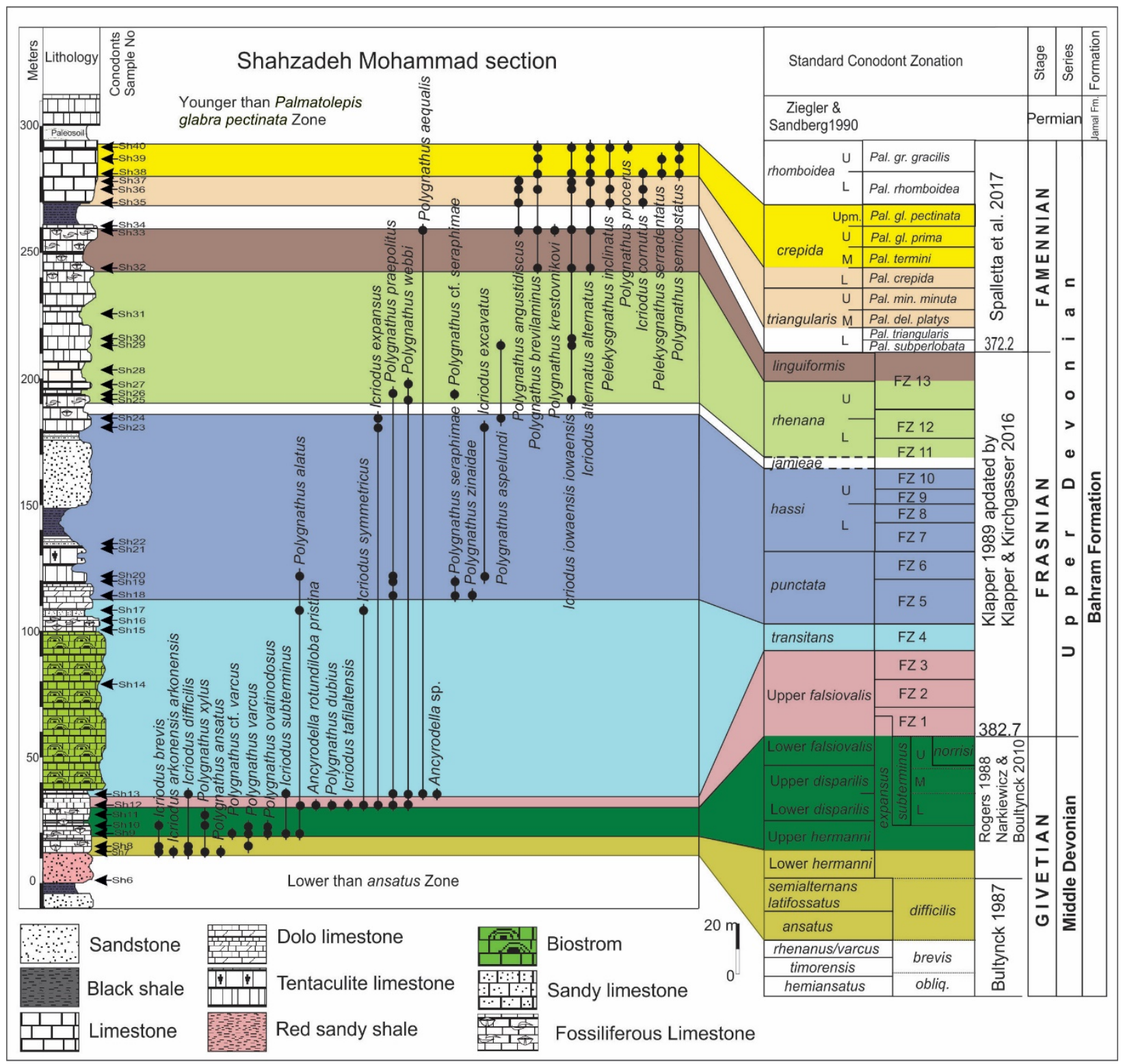

Fig. 4: Stratigraphic log, samples position, conodont occurrences and biozonation of the Shahzadeh Mohammad section. Abbreviations: L: Lower M: Middle, U: Upper, Upm: Uppermost, FZ are from Klapper and Kirchgasser (2016), Bis: Bispathodus, po: Polygnathus, Pal: Palmatolepis, obliq: obliquimarginatus, del: delicatula, min: minuta, gl: glabra, gr: gracilis, marg: marginifera, v: velifer, ac: aculeatus. 


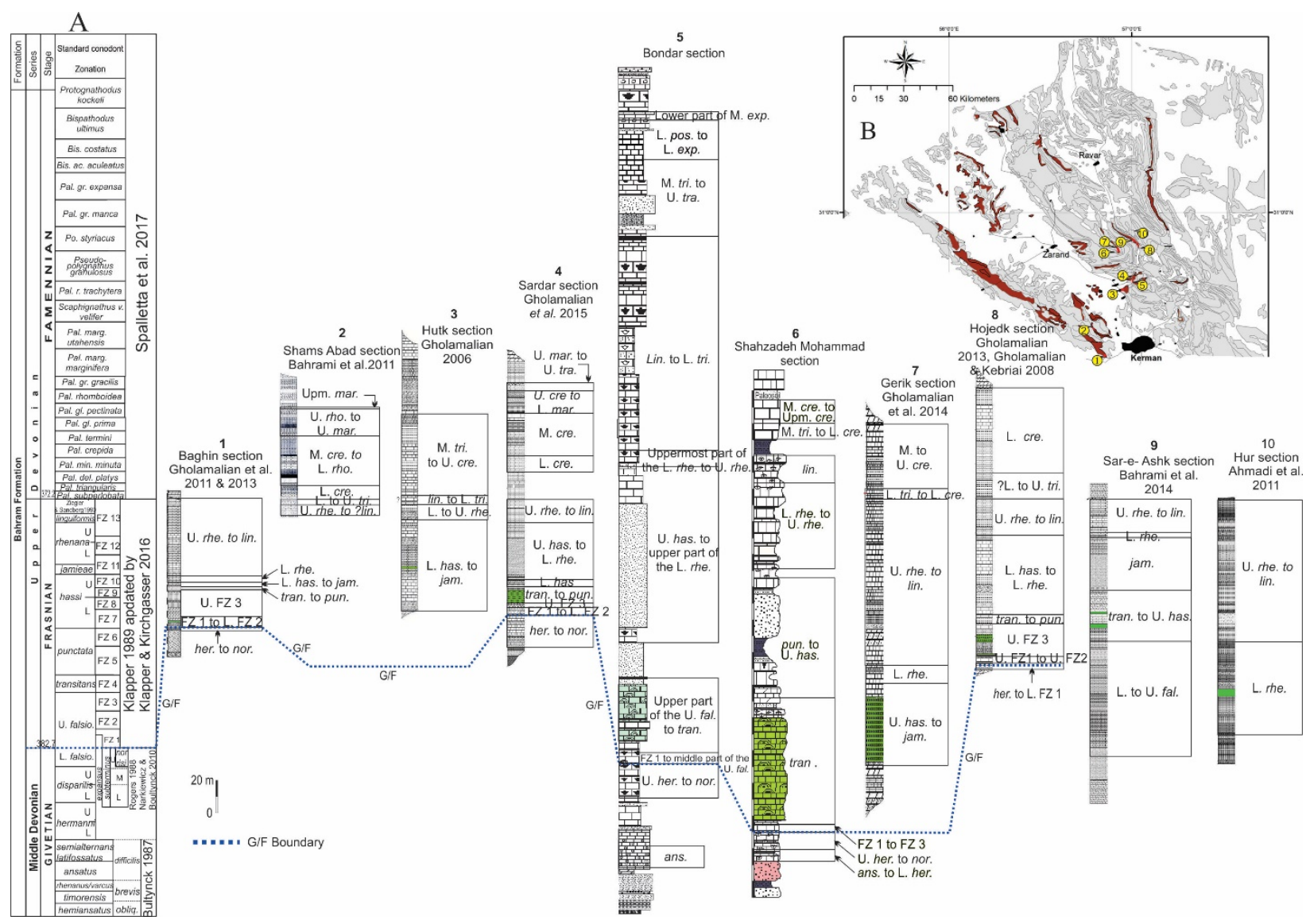

Fig. 5: A) Biostratigraphic correlation of the Bahram Formation stratigraphic sections in the Kerman region (Givetian to Famennian). Abbreviations used for zones: L: Lower, M: Middle, U: Upper, Upm: Uppermost, FZ are from Klapper and Kirchgasser (2016), Bis: Bispathodus, po: Polygnathus, Pal: Palmatolepis, obliq: obliquimarginatus, ans: ansatus, her: hermanni, dis: disparilis, nor: norrisi, fal: falsiovalis, tran: transitans, pun: punctata, has: hassi, jam: jamieae, rhe: rhenana, lin: linguiformis, tri: triangularis, cre: crepida, rho: rhomboidea, mar: marginifera, tra: trachytera, pos:postera, exp: expansa, del: delicatula, min: minuta, gl: glabra, gr: gracilis, marg: marginifera, v: velifer, ac: aculeatus. B) Location of the Devonian sections in Kerman region. 


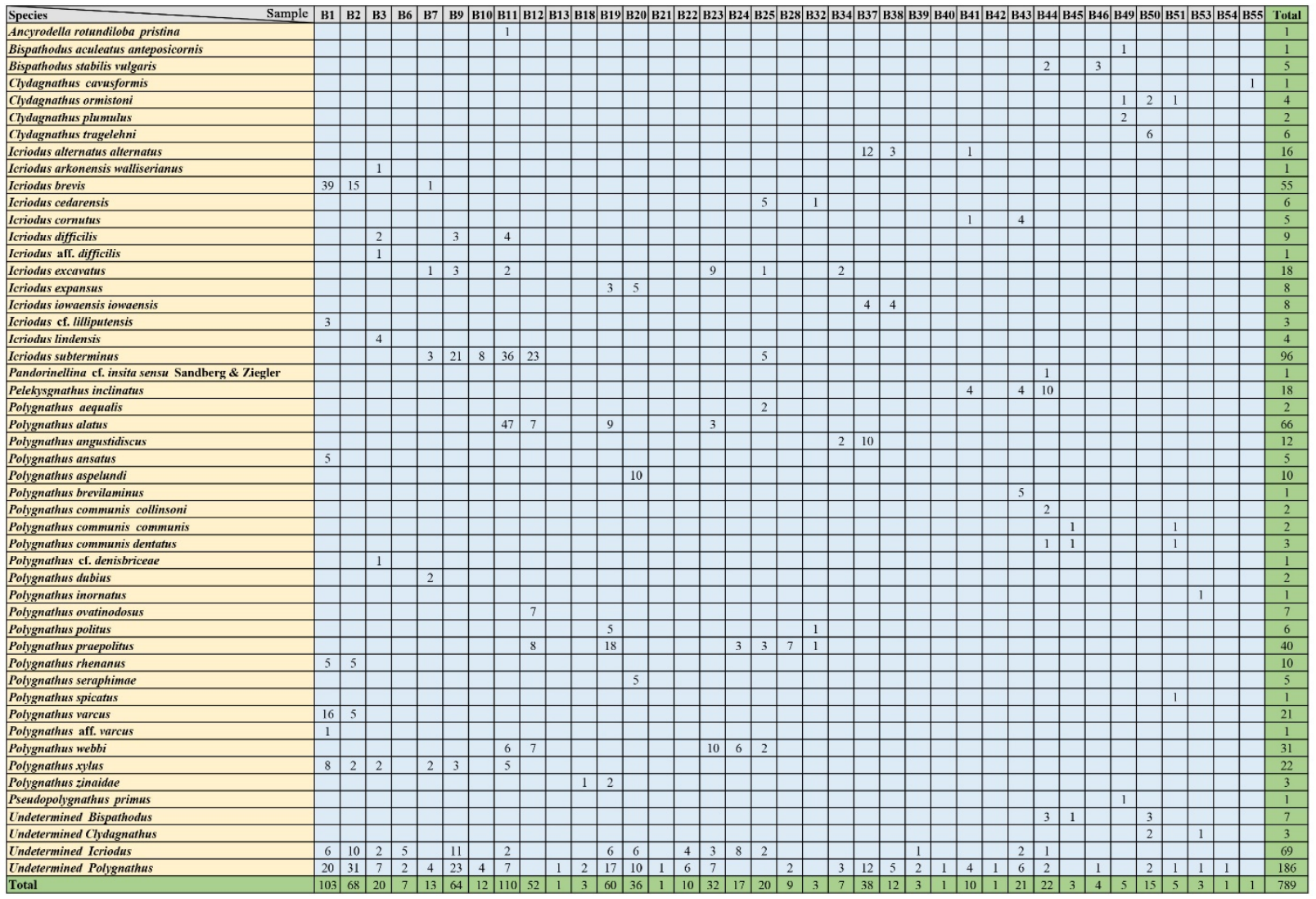

Tab 1: Range chart and abundance of conodont species in the Bondar section.

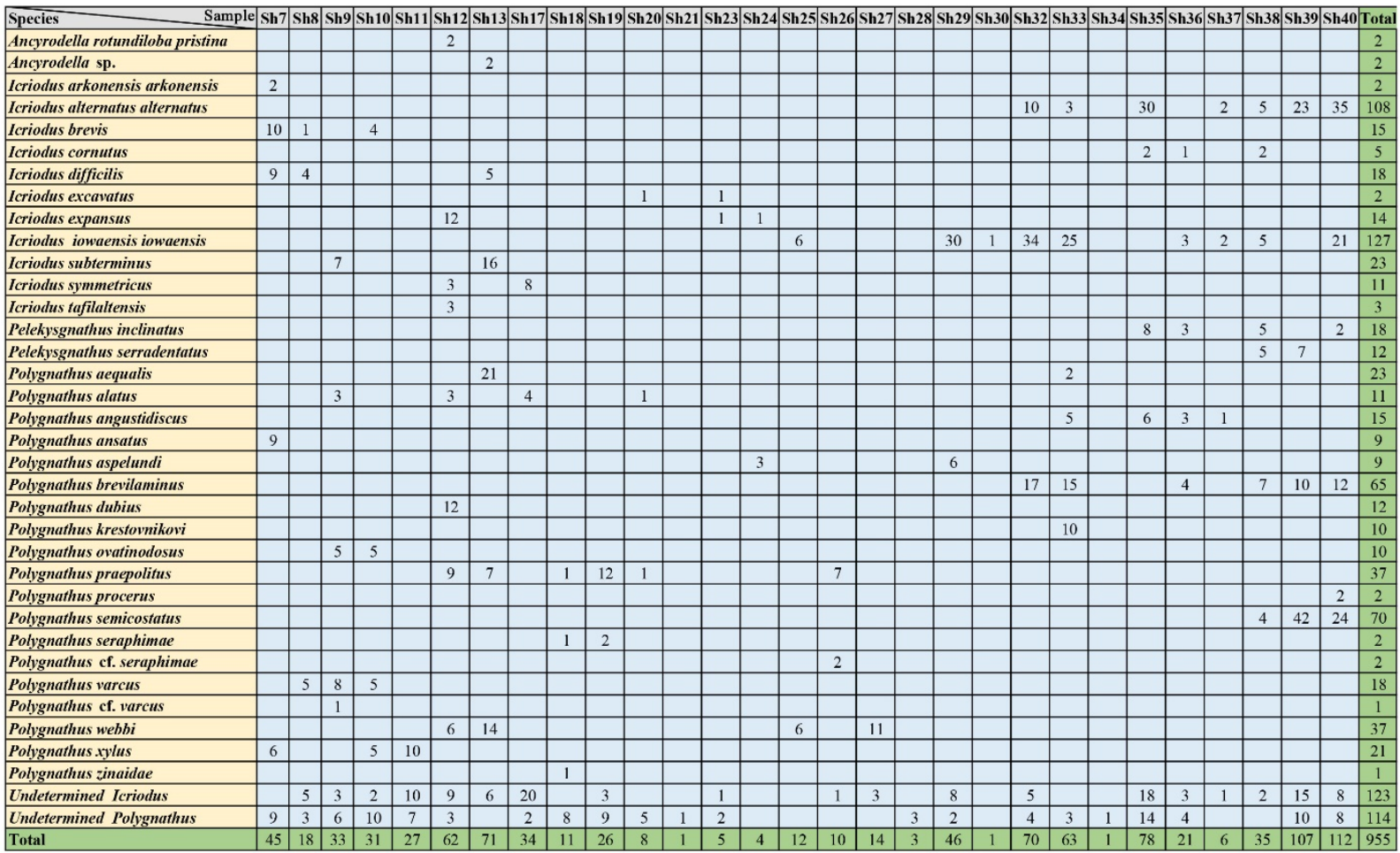

Tab 2: Range chart and abundance of conodont species in the Shahzadeh Mohammad section. 



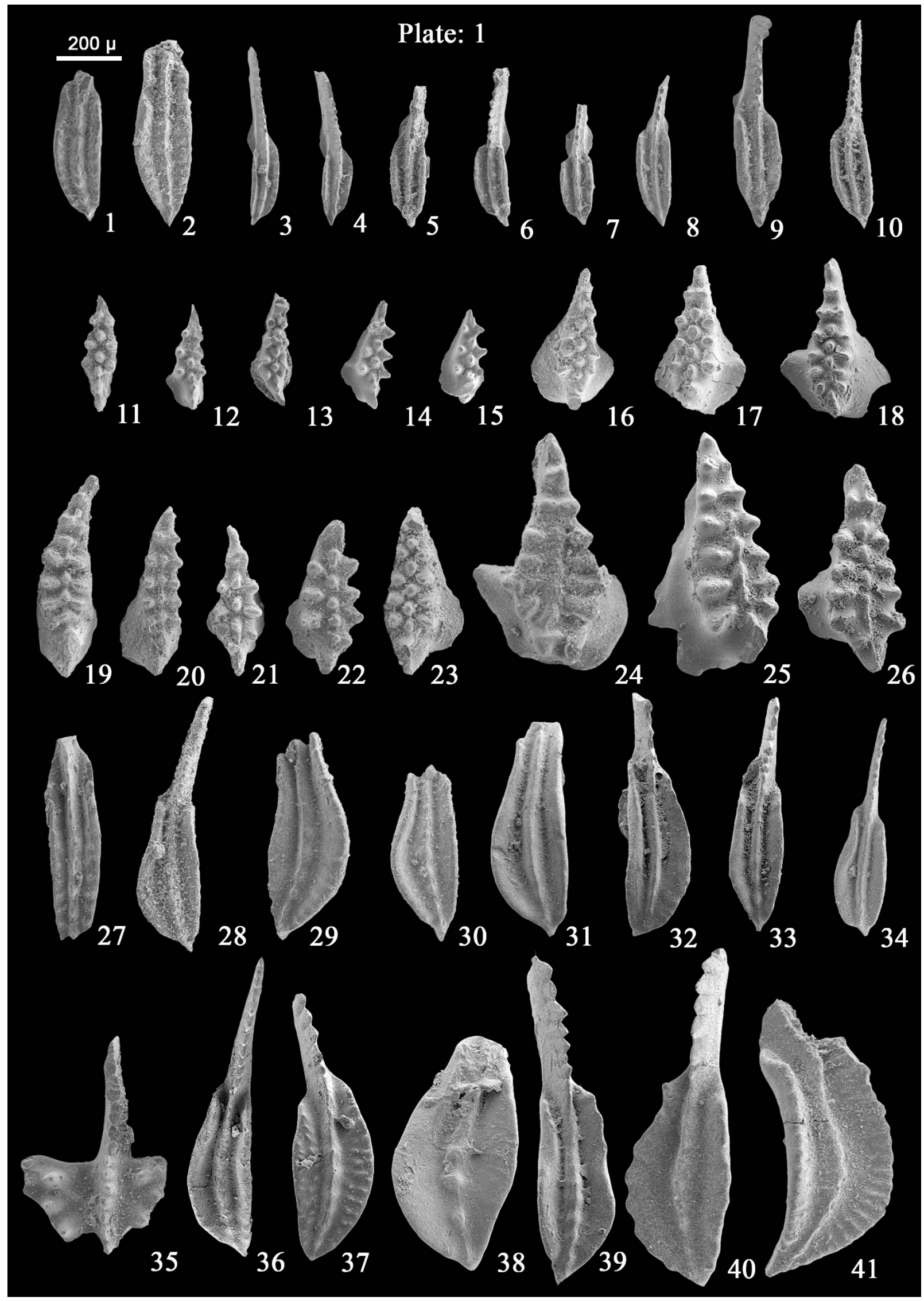


Plate 1 - Selected conodonts from the Bondar section. The collection is stored in the Department of Geology, University of Isfahan. All figured conodonts are P1 and/or I elements.

1, 2- Polygnathus ansatus Ziegler \& Klapper 1976 (in Ziegler, Klapper \& Johnson 1976); (1) upper view of EUIC B235, Sample B1. (2) upper view of EUIC B254, Sample B1.

3, 4- Polygnathus rhenanus Klapper, Philip \& Jackson 1970; (3) upper view of EUIC B238, Sample B1; (4) upper view of EUIC B239, Sample B1.

5-7- Polygnathus varcus Stauffer 1940; (5) upper view of EUIC B300, Sample B2; (6) upper view of EUIC B241, Sample B1; (7) upper view of EUIC B256, Sample B1.

8- Polygnathus aff. varcus Stauffer 1940; upper view of EUIC B255, Sample B1.

9-10- Polygnathus xylus Stauffer 1940; (9) upper view of EUIC B240, Sample B1; (10) upper view of EUIC B286, Sample B2.

11-14- Icriodus brevis Stauffer 1940; (11) upper view of EUIC B264, Sample B1; (12) upper view of EUIC B271, Sample B1; (13) upper view of EUIC B268, Sample B1; (14) upper view of EUIC B269, Sample B1.

15- Icriodus cf. lilliputensis Bultynck 1987; upper view of EUIC B277, Sample B1.

16, 17- Icriodus subterminus Youngquist 1947; (16) upper view of EUIC B385, Sample B11; (17) upper view of EUIC B389, Sample B11.

18- Icriodus difficilis Ziegler, Klapper \& Johnson 1976; upper view of EUIC B402, Sample B11.

19- Icriodus arkonensis walliserianus Weddige 1988; upper view of EUIC B311, Sample B3.

20- Icriodus aff. difficilis Ziegler, Klapper \& Johnson 1976; upper view of EUIC B312, Sample B3.

21- Icriodus lindensis Weddige 1977; upper view of EUIC B315, Sample B3.

22, 23- Icriodus subterminus Youngquist 1947; (22) upper view of EUIC B345, Sample B9; (23) upper view of EUIC B337, Sample B9.

24- Icriodus difficilis Ziegler, Klapper \& Johnson 1976; upper view of EUIC B339, Sample B9.

25, 26- Icriodus expansus Branson \& Mehl 1938; (25) upper view of EUIC B413, Sample B19; (26) upper view of EUIC B414, Sample B19.

27- Polygnathus cf. denisbriceae Bultynck 1979; upper view of EUIC B323, Sample B3.

28-30- Polygnathus alatus Huddle 1934; (28) upper view of EUIC B376, Sample B11; (29) upper view of EUIC B368, Sample B11; (30) upper view of EUIC B381, Sample B11. 
31- Polygnathus praepolitus Kononova, Alekseev, Braskov \& Reimers 1996; upper view of EUIC B417, Sample B19.

32, 33- Polygnathus politus Ovnatanova 1969; (32) upper view of EUIC B418, Sample B19; (33) upper view of EUIC B419, Sample B19.

34- Polygnathus aspelundi Savage \& Funai 1980; upper view of EUIC B422, Sample B20.

35- Ancyrodella rotundiloba pristina, Khalymbadzha \& Chernyscheva 1970; upper view of EUIC B367, Sample B11.

36- Polygnathus praepolitus Kononova, Alekseev, Braskov \& Reimers 1996; upper view of EUIC B403, Sample B12.

37- Polygnathus ovatinodosus Ziegler \& Klapper 1976; upper view of EUIC B405, Sample B12.

38, 39- Polygnathus zinaidae Kononova, Alekseev, Braskov \& Reimers 1996; (38) upper view of EUIC B412, Sample B18; (39) upper view of EUIC B420, Sample B19.

40- Polygnathus seraphimae Ovnatanova \& Kononova 1996; upper view of EUIC B425, Sample B20.

41- Polygnathus webbi Stauffer 1938; upper view of EUIC B433, Sample B23. 


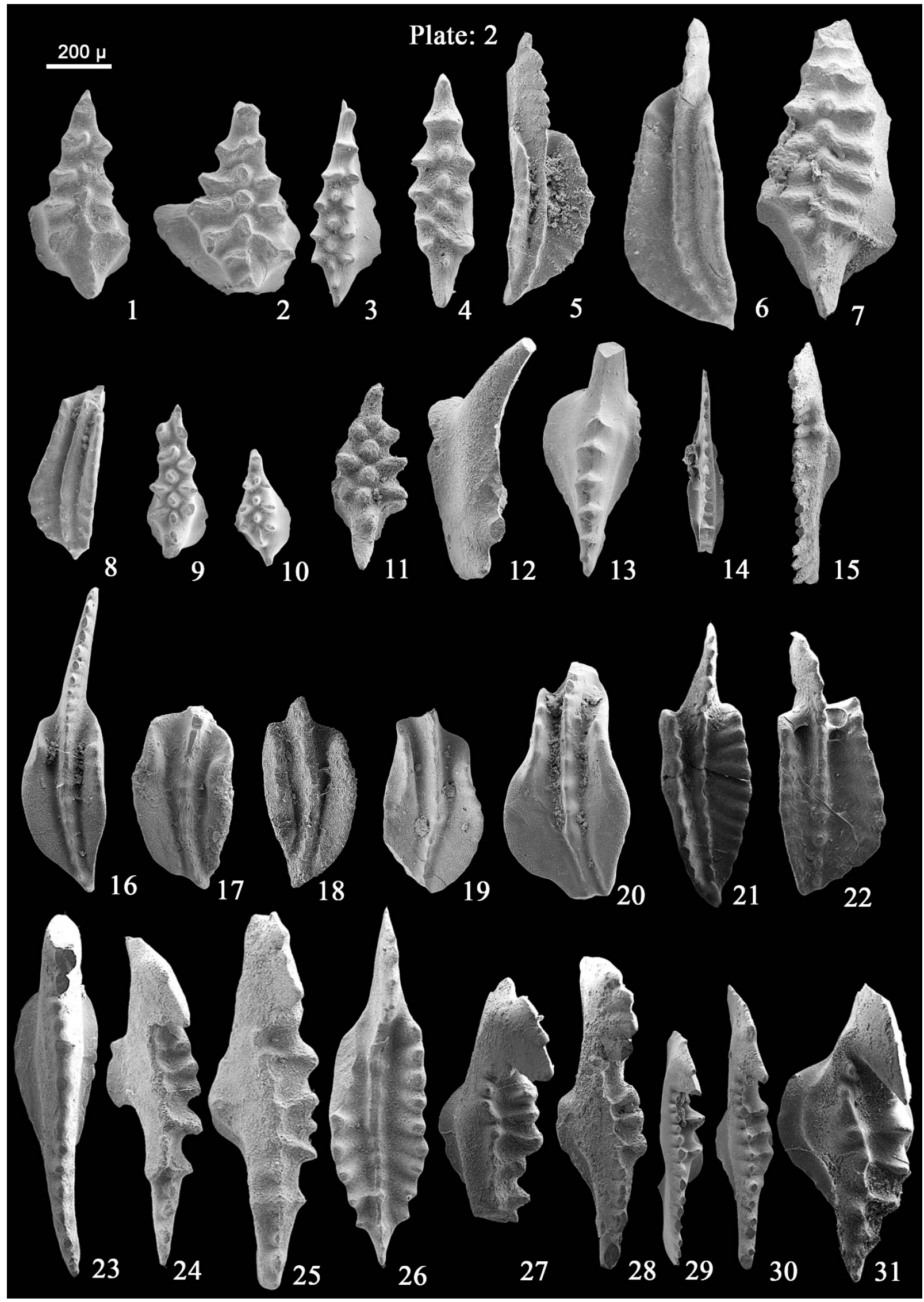


Plate 2: Selected conodonts from the Bondar section. The collection is stored in the Department of Geology, University of Isfahan. All figured conodonts are P1 and/or I elements.

1, 2- Icriodus excavatus Weddige 1984; (1) upper view of EUIC B440, Sample B23; (2) upper view of EUIC B443, Sample B23.

3, 4- Icriodus alternatus alternatus Branson \& Mehl 1934; (3) upper view of EUIC B468, Sample B37; (4) upper view of EUIC B467, Sample B37.

5, 6- Polygnathus webbi Stauffer 1938; (5) upper view of EUIC B448, Sample B24; (6) upper view of EUIC B450, Sample B25.

7- Icriodus iowaensis iowaensis Youngquist \& Peterson 1947; upper view of EUIC B470, Sample B37.

8- Polygnathus aequalis Klapper and Lane (1985); (8) upper view of EUIC B452, Sample B25.

9, 10- Icriodus cedarensis Narkiewics \& Bultynck 2010; (9) upper view of EUIC B458, Sample B25; (10) upper view of EUIC B460, Sample B25.

11- Icriodus cornutus Sannemann 1955; upper view of EUIC B477, Sample B43.

12, 13- Pelekysgnathus inclinatus Thomas 1949; (12) oblique-lateral view of EUIC B479, Sample B43; (13) upper view of EUIC B483, Sample B44.

14- Bispathodus stabilis vulgaris Dzik 2006; upper view of EUIC B492, Sample B44.

15- Bispathodus aculeatus anteposicornis Scott 1961; upper view of EUIC B499, Sample B49.

16, 17- Polygnathus communis dentatus Druce 1969; (16) upper view of EUIC B489, Sample B44; (17) upper view of EUIC B496, Sample B45.

18- Polygnathus communis communis Branson \& Mehl 1934; upper view of EUIC B495, Sample B45.

19, 20- Polygnathus communis collinsoni Druce 1969; (19) upper view of EUIC B491, Sample B44; (20) upper view of EUIC B490, Sample B44.

21- Polygnathus spicatus Branson 1934; upper view of EUIC B515, Sample B51.

22- Polygnathus inornatus Branson \& Mehl 1934; upper view of EUIC B517, Sample B53.

23- Pandorinellina cf. insita sensu Sandberg \& Ziegler 1979; upper view of EUIC B486, Sample B44.

24, 25- Clydagnathus plumulus Rhodes et al. 1969; (24) upper view of EUIC B501, Sample B49; (25) upper view of EUIC B502, Sample B49.

26- Pseudopolygnathus primus Branson \& Mehl 1934; upper view of EUIC B503, Sample B49. 
27- Clydagnathus ormistoni Beinert, Klapper, Sandberg \& Ziegler 1971; upper view of EUIC B505, Sample B50.

28-30- Clydagnathus tragelehni Hartenfels 2011; (28) upper view of EUIC B506, Sample B50; (29) upper view of EUIC B508, Sample B50; (30) upper view of EUIC B509, Sample B50.

31- Clydagnathus ormistoni Beinert, Klapper, Sandberg \& Ziegler 1971; upper view of EUIC B512, Sample B51. 


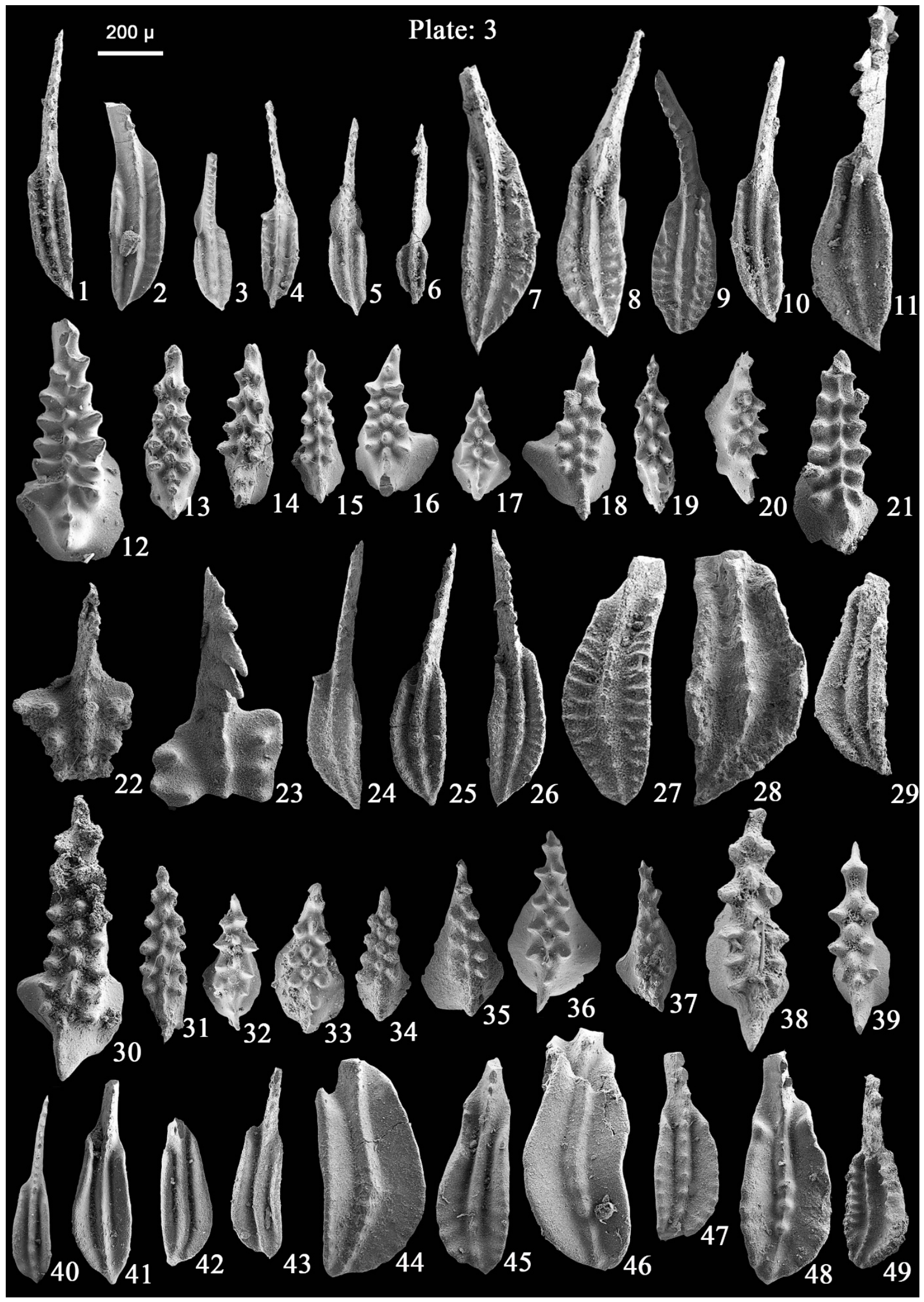


Plate 3 - Selected conodonts from the Shahzadeh Mohammad section. The collection is stored in the Department of Geology, University of Isfahan. All figured conodonts are P1 and/or I elements.

1- Polygnathus xylus Stauffer 1940; upper view of EUIC S519, Sample Sh7.

2- Polygnathus ansatus Ziegler \& Klapper 1976 (in Ziegler, Klapper \& Johnson 1976); upper view of EUIC S523, Sample Sh7.

3, 5-6- Polygnathus varcus Stauffer 1940; (3) upper view of EUIC S543, Sample Sh8; (5) upper view of EUIC S551, Sample Sh9; (6) upper view of EUIC S557, Sample Sh10.

4- Polygnathus cf. varcus Stauffer 1940; upper view of EUIC S545, Sample Sh9.

7-9- Polygnathus ovatinodosus Ziegler \& Klapper 1976; (7) upper view of EUIC S546, Sample Sh9; (8) upper view of EUIC S547, Sample Sh9; (9) upper view of EUIC S560, Sample Sh10.

10- Polygnathus xylus Stauffer 1940; upper view of EUIC S558, Sample Sh10.

11- Polygnathus alatus Huddle 1934; upper view of EUIC S568, Sample Sh12.

12- Icriodus arkonensis arkonensis Stauffer 1938; upper view of EUIC S527, Sample Sh7.

13-15, 19, 20- Icriodus brevis Stauffer 1940; (13) upper view of EUIC S530, Sample Sh7; (14) upper view of EUIC S534, Sample Sh7; (15) upper view of EUIC S555, Sample Sh10; (19) upper view of EUIC S529, Sample Sh7; (20) upper view of EUIC S538, Sample Sh8.

16-18- Icriodus difficilis Ziegler, Klapper \& Johnson 1976; (16) upper view of EUIC S532, Sample Sh7; (17) upper view of EUIC S539, Sample Sh8; (18) upper view of EUIC S588, Sample Sh13.

21- Icriodus tafilaltensis Narkiewics \& Bultynck 2010; upper view of EUIC S579, Sample Sh12.

22, 23- Ancyrodella rotundiloba pristina, Khalymbadzha \& Chemysheva 1970; (22) upper view of EUIC S566, Sample Sh12; (23) upper view of EUIC S567, Sample Sh12.

24, 25- Polygnathus praepolitus Kononova, Alekseev, Braskov \& Reimers 1996; (24) upper view of EUIC S570, Sample Sh12; (25) upper view of EUIC S574, Sample Sh12.

26- Polygnathus dubius Hinde 1879; upper view of EUIC S573, Sample Sh12.

27-29- Polygnathus aequalis Klapper \& Lane 1985; (27) upper view of EUIC S593, Sample Sh13; (28) upper view of EUIC S594, Sample Sh13; (29) upper view of EUIC S595, Sample Sh13.

30, 31- Icriodus symmetricus Branson \& Mehl 1934; (30) upper view of EUIC S600, Sample Sh17; (31) upper view of EUIC S580, Sample Sh12. 
32-34- Icriodus subterminus Youngquist 1947; (32) upper view of EUIC S552, Sample Sh9; (33) upper view of EUIC S553, Sample Sh9; (34) upper view of EUIC S587, Sample Sh13.

35-37- Icriodus expansus Branson \& Mehl 1938; (35) upper view of EUIC S584, Sample Sh12; (36) upper view of EUIC S614, Sample Sh23; (37) upper view of EUIC S616, Sample Sh24.

38-39- Icriodus cornutus Sannemann 1955; (38) upper view of EUIC S683, Sample Sh35; (39) upper view of EUIC S697, Sample Sh38.

40-43- Polygnathus praepolitus Kononova, Alekseev, Braskov \& Reimers 1996; (40) upper view of EUIC S603, Sample Sh18; (41) upper view of EUIC S607, Sample Sh19; (42) upper view of EUIC S612, Sample Sh20; (43) upper view of EUIC S625, Sample Sh26.

44, 45- Polygnathus alatus Huddle 1934; (44) upper view of EUIC S599, Sample Sh17; (45) upper view of EUIC S611, Sample Sh20.

46- Polygnathus zinaidae Kononova, Alekseev, Braskov \& Reimers 1996; upper view of EUIC S605, Sample Sh18. 47, 48- Polygnathus seraphimae Ovnatanova \& Kononova 1996; (47) upper view of EUIC S604, Sample Sh18; (48) upper view of EUIC S609, Sample Sh19;

49- Polygnathus cf. seraphimae Ovnatanova \& Kononova 1996; upper view of EUIC S622, Sample Sh26. 


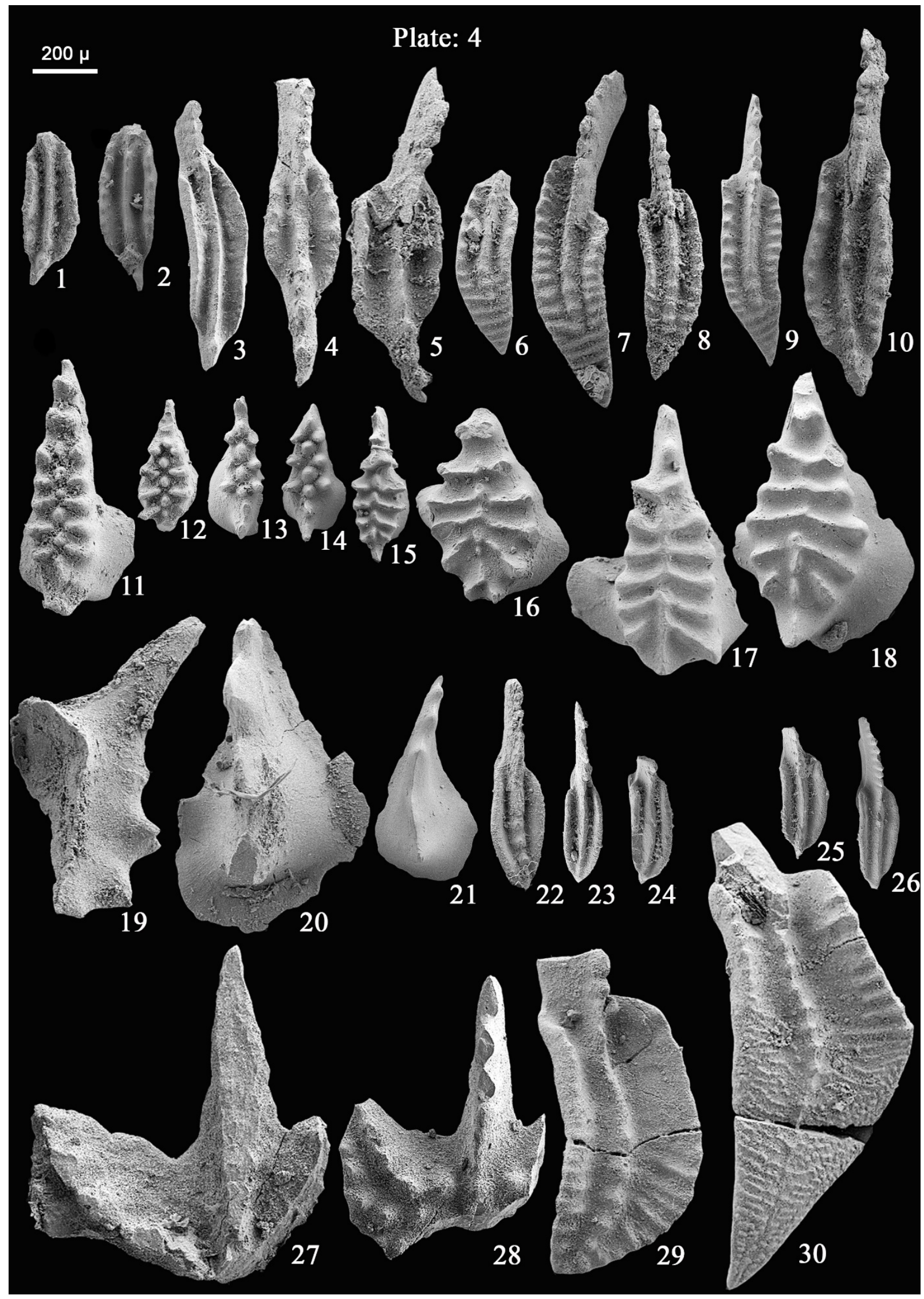


Plate 4 - Selected conodonts from the Shahzadeh Mohammad section. The collection is stored in Department of Geology, University of Isfahan. All figured conodonts are P1 and/or I elements.

1-3- Polygnathus brevilaminus Branson \& Mehl 1934; (1) upper view of EUIC S657, Sample Sh32; (2) upper view of EUIC S660, Sample Sh40; (3) upper view of EUIC S724, Sample Sh33.

4, 5- Polygnathus angustidiscus Youngquist 1945; (4) upper view of EUIC S658, Sample Sh33; (5) upper view of EUIC S687, Sample Sh36.

6-9- Polygnathus semicostatus Branson \& Mehl 1934; (6) upper view of EUIC S700, Sample Sh38; (7) upper view of EUIC S705, Sample Sh39; (8) upper view of EUIC S708, Sample Sh39; (9) upper view of EUIC S719, Sample $\operatorname{Sh} 40$.

10- Polygnathus procerus Sannemann 1955; upper view of EUIC S723, Sample Sh40.

11-14- Icriodus alternatus alternatus Branson \& Mehl 1934; (11) upper view of EUIC S696, Sample Sh38; (12) upper view of EUIC S651, Sample Sh32; (13) upper view of EUIC S682, Sample Sh35; (14) upper view of EUIC S732, Sample Sh40.

15-18- Icriodus iowaensis iowaensis Youngquist \& Peterson 1947; (15) upper view of EUIC S636, Sample Sh29; (16) upper view of EUIC S644, Sample Sh32; (17) upper view of EUIC S670, Sample Sh33; (18) upper view of EUIC S666, Sample Sh33.

19- Pelekysgnathus inclinatus Thomas 1949; lateral view of EUIC S734, Sample Sh40.

20, 21- Pelekysgnathus serradentatus Capkinoglu 1991; (20) upper view of EUIC S699, Sample Sh38; (21) upper view of EUIC S710, Sample Sh39.

22, 23- Polygnathus praepolitus Kononova, Alekseev, Braskov \& Reimers 1996; (22) upper view of EUIC S623, Sample Sh26; (23) upper view of EUIC S624, Sample Sh26.

24-26- Polygnathus aspelundi Savage \& Funai 1980; (24) upper view of EUIC S 619, Sample Sh24; (25) upper view of EUIC S618, Sample Sh24; (26) upper view of EUIC S630, Sample Sh29.

27, 28- Ancyrodella sp.; (27) upper view of EUIC S598, Sample Sh13; (28) upper view of EUIC S597, Sample Sh13.

29- Polygnathus webbi Stauffer 1938; upper view of EUIC S628, Sample Sh27.

30- Polygnathus krestovnikovi Ovnatanova 1969; upper view of EUIC S662, Sample Sh33. 